\title{
Pandemide Altından Mücevher Tüketimi
}

DOI: $10.26466 /$ opus. 941168

\author{
Selahattin Armağan Vurdu* \\ *Öğr.Gör. Dr., İstanbul Ticaret Üniversitesi, Dış Ticaret Enstitüsü, İstanbul/Türkiye \\ E-Posta: armagan.vurdu@immib.org.tr \\ ORCID: $0000-0002-5836-876 \mathrm{X}$
}

\section{Öz}

Covid-19 pandemisi küresel ekonominin daralmasına, üretim ve ticaret hacminin azalmasına, belirsizliğin artmasına ve tüketici davranışlarının değişmesine yol açmışıtı. Pandeminin neden olduğu toplumsal ve ekonomik zararlarm giderilmesi, ekonomik aktivitenin artırılması için hükümetler destek paketleri açıklamıştır. Ancak belirsizlik ortamı ve virüsün yayılmasını engelleme amaçlı alınan tebdirler tüketici tasarruflarının artmasına, tüketicinin zaruri tüketim malları dışındaki toplumsal ve lüks harcamaların azaltmasına sebep olmuştur. Bu çalışmada pandemi ekonomisinde tüketici satınalma davranışlarm etkileyen faktörler, bir lüks tüketim çeşidi olarak mücevherata talebin pandemi öncesi ile karşılaştırmalı durumu, küresel mücevher tüketiminde önemli rol oynayan ülkeler olarak Çin, Hindistan, ABD ile Türkiye'nin performansı incelenmektedir. Çalışmada Türkiye'de altından mücevher talebi Mann-Kendall Seasonality Test metodu ile trend analizine tabi tutulmaktadır. Statü göstergesi olarak toplumsal tüketimi olan altından mücevher Türkiye'de minimum değer kaybryla kolayca nakde çevrilebilmesi özelliği göz önünde bulundurularak daha çok yüksek ayar olarak tüketilmekte, lüks tasarruf aracı olarak görülmektedir. Tüketicilerin tasarruflarını artırma ĕ̆ilimi içerisinde olduğu pandemi ekomisinde, altından mücevherin lüks tasarruf aracı olarak görülmesi Türkiye'nin dünya talebindeki payını koruyabilmesinin en önemli nedenleri arasında değerlendirilmektedir.

Anahtar Kelimeler: Covid-19, Tüketici Davranışı, Altından Mücevher, Lüks Tasarruf. 


\title{
Gold Jewelry Consumption in Pandemic
}

\begin{abstract}
The Covid-19 pandemic has led to the contraction of the global economy, decrease in production and trade volume, increase in uncertainty and change in consumer behavior. Governments have announced support packages in order to eliminate the social and economic damages caused by the pandemic and to increase economic activity. However, the increasing uncertainty and the measures taken to prevent the spread of the virus led to an increase in consumer savings, and a decrease in social and luxury expenditures other than essential consumer goods. In this study, the factors affecting consumer purchasing behavior in the pandemic economy, the status of the demand for jewelry as a luxury consumption type in the pandemic compared with pre-pandemic, the performance of China, India, the USA and Turkey as countries that played an important role in global jewelry consumption are examined. In the study, gold jewelry demand in Turkey is subjected to trend analysis with the Mann-Kendall Seasonality Test method. Gold jewelry, which is socially consumed as a status indicator, is mostly consumed as a highcaliber, luxury saving tool, considering its ability to be easily converted into cash with minimal depreciation in Turkey. Considering gold jewelry a luxury saving tool in the pandemic economy, where consumers tend to increase their savings, is considered one of the most important reasons for Turkey to maintain its share in the world demand during this period.
\end{abstract}

Keywords: Covid-19, Consumer Behavior, Gold Jewelry, Luxury Saving. 


\section{Giriş}

Aralık 2019'da Çin'de görülen ve Dünya Sağlık Örgütü tarafından Mart 2020'de pandemi olarak kabul edilen Covid-19, 2020 yılında küresel ekonomiyi daraltan, üretim ve ticaret hacmini azaltan, iş yapış şekillerini değiştiren bir virüs olmuştur. Lüks tüketim malı olan altından mamul mücevherci eşyası dünya genelinde küresel salgının neticelerinden en çok etkilenen sektörlerin başında gelmiştir. Pandemi ekonomisinin getirdiği işsizlik, belirsizlik ve salgının yayılmasını engellemeye yönelik alınan tedbirler tüketici davranışlarını etkilemiştir. $\mathrm{Bu}$ çalışmada pandemi koşullarında tüketici davranışlarını etkileyen göstergeler ışığında dünyada ve Türkiye'de altından mücevherci eşyasının tüketimindeki değişim incelenecektir.

Bu doğrultuda öncelikle ekonomik çerçevenin çizilmesi adına; Covid19 pandemi ekonomisinde tüketici davranışlarını etkileyen işsizlik, hanehalkı geliri, gelire etkide bulunan hükümet destekleri ve tüketicinin harcama ve tasarruf eğilimlerini belirleyen tüketicinin gelecek beklentisi incelenecektir. Ardından altından mücevherin yer ve zamana göre değişen ekonomik ve toplumsal işlevlerine değinilecek olup son bölümde ise makroenonomik göstergeler ve kavramsal araçlar yardımıyla dünyadaki belli başlı mücevher tüketici ülkeleri ve Türkiye'nin altından mücevher talep rakamları değerlendirilecektir. Mann-Kendall Seasonality Test metodu kullanılarak 2018-2020 yılları arası Türkiye altından mücevher talep trendi araştırılacaktır.

\section{Pandemi Ekonomisinde Tüketimi Etkileyen Faktörler}

En son 2008'de Finans Krizi ile tanık olunan küresel resesyonlar arasında 2020 pandemisinin İkinci Dünya Savaşı'ndan sonra dünyanın yaşadığı en derin resesyona sebep olarak tarihe geçmesi beklenmektedir (Kose, Ohnsorge ve Vorisek, 2021, s. 13). 2019 sonu ve 2020'nin ilk çeyreğinde Çin'i etkileyen pandeminin negatif etkisi, 2020'nin ikinci çeyreğinde dünya genelinde tüm ekonomilerde gözlemlenmiştir. 2020'de virüsün bulaş rakamlarının artması, aşının bulunacağı zamanın bilinememesi, belirsizlik, tüketicinin güvensiz ortamda stoklama isteğiyle talep şoku yaratması ve dünya tedarik zincirlerindeki aksamalar sebebiyle arz şokunun 
yaşanması, bulaş riskini engellemek için hükümetlerce alınan toplumsal ve ekonomik önlemler tüm dünya gündeminin en üst sıralarında yer tutmuştur.

2020 yılı, belirsizliğin had safhada olduğu dönemde yapılan ekonomik daralma tahminleri kadar karamsar bir tablo ile sonuçlanmamıştır. Özellikle ikinci yarıda birçok ülke ekonomisi toparlanma eğilimi göstermiştir. OECD'nin Mart 2021 tarihli raporuna göre 2020 yllında dünya reel Gayri Safi Yurt İçi Hâsıla (GSYİH) daralmasının \%3,4 mertebesinde gerçekleştiği tahmin edilmektedir (Organisation for Economic Co-operation and Development [OECD], 2021b, s.4). \%11'lik GSYİH rekor daralmasıyla İspanya Avrupa' da en çok daralan ekonomi olmuştur (OECD, 2021b, s.4). Birleşik Krallık ekonomisi ise 2020 yılında \%9,9'luk GSYİH daralmasıyla 300 yıldır yaşamadığ1 oranda küçülmüştür (Romei ve Giles, 2021). 2020'de Hindistan \%7,4; Japonya \%4,8; ABD \%3,5 oranında ekonomik olarak küçülürken Çin $\% 2,3$; Türkiye ise $\% 1,8$ oranında büyüme oranları kaydetmiştir (OECD, 2021b, s.4).

\section{İşsizlik}

Pandemi döneminde artan işsizlik tüketicilerin kullanılabilir gelirini ve beklentilerini etkileyen faktörlerden biri olmuştur. Virüsün yayılmasını engellemek amacıyla alınan önlemler en çok seyahat, turizm, yeme-içme gibi sektörleri derinden etkilemiş, özellikle hizmet sektörü başta olmak üzere tüm sektörlerde işsizliği arttırmıştır. İşsizlik, ABD'de 2020 Nisan ayında Büyük Buhran'dan sonra görülmedik düzeye \%14,7'lere kadar çıkmış; Mayıs 2020'den itibaren azalmaya başlayan oran pandemi öncesi orana henüz ulaşamamış olsa da Mart 2021'de \%6'ya kadar düşmüştür. (Bureau of Labour Statistics, 2021). ABD'deki 26 eyaletin işsizlik rakamlarının sektörlere göre dağglımını inceleyen çalışma ise işsizliğin daha çok mücevherin de dâhil olduğu rekreasyon ve hayırseverlik sektörlerinde meydana geldiğini ortaya koymuştur (Roy vd., 2021, s. 2). Avrupa bölgesinde ise pandeminin etkisi işsizlik oranlarında 2020 Nisan ayında hissedilmeye başlamış olup üçüncü çeyrekte Ağustos ayında \%7,8 oranıla en yüksek noktasına çıkmıştır (EUROSTAT, 2021). Dünya altından mamul tüketiminde önemli paya sahip Hindistan'da ise işsizlik oranı Nisan ayında rekor kırarak \%23,5 seviyelerine yükselmiştir (Centre for 
Monitoring Indian Economy [CMIE], 2021). Dünya'daki genel işsizlik artışına paralel olarak Türkiye' de de Mart 2020'de artan mevsim etkilerinden arındırılmış işsizlik oranı Temmuz ayında \%14,5 ile en tepe noktasına ulaşmış; Ocak 2021'de \%12,2'ye kadar gerilemiştir (Türkiye İstatistik Kurumu [TÜIKK], 2021).

\section{Gelir}

Tüketici tercihlerini etkileyen diğer önemli etmen ise gelirdir. Pandemi döneminde artan işsizlik birçok hanede gelirin azalmasına sebep olmuştur. Ancak hükümetlerin pandeminin negatif etkisini azaltmak maksadıyla sağladığı ekonomik destekler, kimi ülkelerde artan işsizliğe rağmen tüketicinin harcamasını etkileyen hanehalkı gelirinde artış yaşanmasını sağlamıştır. Mevsimsel etkilerden arındırılmış veriye göre 2020'nin ikinci çeyreğinde bir önceki çeyreğe kıyasla Kanada'da kişi başına düşen reel hanehalkı geliri \%11, ABD'de \%10,1 oranında artarken; İtalya'da \%7,2, Birleşik Krallık'ta \%3,4, Fransa'da \%2,3 azalmıştır. OECD bölgesinde kişi başına düşen reel GSYİH'deki keskin \%10,6'lık daralmaya rağmen Kanada ve ABD'nin hanehalkı gelirindeki artış etkisi sebebiyle bölgedeki kişi başına düşen hanehalkı geliri \%5,3 oranında artmıştır (OECD, 2020). 2020'nin üçüncü çeyreğinde bir önceki çeyreğe kıyasla mevsimsel etkilerden arındırılmış veriye göre kişi başına düşen reel hanehalkı geliri ABD'de \%4,2 ve Kanada'da \%3,6 düşmüş; İtalya'da \%6,4, Birleşik Krallık'ta \%5,1, Almanya'da \%4,3 artmıştır. Üçüncü çeyrekte OECD bölgesinde kişi başına düşen reel GSYİH'deki \%9,1'lik artışa rağmen kişi başına düşen reel hanehalkı geliri sadece $\% 0,6$ oranında artmiştır (OECD, 2021a). Hindistan'da ise hanehalkı gelirinde düşüş yaşayanların oranı 2020 Şubat ayında \%8,8 iken 25 Mart'ta karantinaya gidilmesiyle bu oran keskin artış yaşayıp Nisan'da \%43,7'e çıkmıştır. (STATISTA, 2021) Karantina döneminde devletin yaptığ1 yardımlar artmış olmakla birlikte toplam gelirdeki oranının oldukça küçük olması sebebiyle ortalama Hintli bir hanehalkının gelirini dengelemede rol oynayamamıştır (Bertrand, Dizon-Ross, Krishnan, ve Schofield, 2020). 


\section{Beklenti}

Tüketici davranışlarını yalnızca içinde bulunulan ekonomik gerçeklikler değil tüketicinin içinde bulunduğu durumu nasıl algıladığı, bu çerçevede ekonomiye duyduğu güveni ve geleceğe dair beklentisi de etkilemektedir. Pandemi döneminde belirsizlik, 1929-1933 Büyük Buhran zamanını seviyeleri ile karşılaştırılabilecek noktaya erişmiştir (Baker, Bloom, Davis, ve Terry, 2020, s.7). Oluşan bu belirsizlik yalnızca piyasaları, altın fiyatlarını etkilememiş tüketicinin ekonomiye güveni ve gelecekten beklentilerini de etkilemiş, tüketim alışkanlıklarını değiştirmiştir. OECD'nin ülke karşılaştırmalı tüketici güven endeksi 2020'de 2009 yılından sonra yaşanan en düşük seviyeye düşmüştür (OECD, 2021b). Söz konusu endekste 100'ün üzerinde değer alan Çin' de tüketici güveni Haziran 2020'de en düşük noktaya geriledikten sonra artış yaşamıştır. OECD ülkeleri tüketici güveni ise Mart 2020'de 100 puanın altına düşmüş, Mayıs'ta 97.59 puan ile en son 2009 'da yaşanan 96.47 'lik tüketici güvensizliği noktasına yaklaşmış olup bu noktadan sonra toparlanmaya başlamıştır. Birleşik Krallık ve Türkiye de Kasım 2020'deki en dip noktadan sonra tüketici güveninde artış yaşayan ülkelerden olmuştur (OECD, 2021b).

\section{Harcama, Tasarruf ve Tüketim}

Belirsizliğin artması ve Covid-19 önlemleriyle seyahat, dışarıda yeme içme imkânlarının kısıtlanması farklı gelir gruplarındaki tüketicileri tasarrufa itmiştir. The Economist dergisi 21 zengin ülkenin vergisi çıkarılmış geliri ile tüketici harcamasını derlemiş ve pandemi olmasaydı 2020 yılının ilk 3 çeyreğinde 3 trilyon dolar tasarruf edecekken pandemi zamanında 6 trilyon kişisel tasarruf yapıldığını belirtmiştir. Bu 3 trilyon dolarlık fazla tasarruf miktarı ise söz konusu ülkelerin yıllık tüketici harcamasının yüzde onuna tekabül etmekte olup ABD Başkanı Biden'ın 1,9 trilyon dolarlık destek paketinin de ABD'nin fazla tasarruflarının GSYİH'sinin \%10'unu aşmasına neden olabileceği öngörülmektedir (The Economist, 2021).

2020'nin ilk üç çeyreğinde GSYİH'sine oranla en çok fazladan tasarruf yapan ülkeler Kanada, ABD ve Birleşik Krallık olmuştur (The Economist, 2021). ABD'de merkez bankası mevduat hesaplarında 2020 Ocak başında 
yaklaşık 13,2 trilyon dolar bulunurken 2021 Mart ayı itibariyle toplam 16,7 trilyon dolara yükseldiği görülmektedir (Federal Reserve Bank of St. Louis, 2021). 2020 başında kişisel tasarrufların oranı \%7,6 iken Nisan 2020 'de \%33,7'ye çıkmış olup 2020 yazında azalan tasarruf oranı Ocak 2021 'de yeniden yatan destek bedeli ile tekrardan \%20,5'e erişmiştir. $\mathrm{ABD}^{\prime}$ de tüketicilerin devlet desteklerini harcama yerine daha çok biriktirme eğiliminde olduğu görülmektedir. Refinitiv iş birliği ile Maru Public Opinion'ın Ocak 2021'de yaptığı ankete göre devlet desteğini biriktirmeyi planlayanların oranı \%48, borçlarını ödemeyi planlayanların oranı ise \%32'dir (Refinitiv, 2021).

Pandeminin görüldüğü ilk evrelerde ABD'de 26 Şubat ile 10 Mart arasında stoklama amacıyla yapılan market alışverişi sebebiyle hanehalkı harcama rakamlarında yaklaşık \%50'lik ani yükseliş ve ardından keskin düşüş gerçekleşmiştir (Baker, Farrokhnia, Meyer, Pagel ve Yannelis, 2020, s.3). 2020 Mart ortalarında yüksek gelir grubunun harcaması ise özellikle Covid vakalarının yüksek olduğu bölgelerde ve yüz yüze iletişim gerektiren sektörlerde, sağlık endişeleri sebebiyle bir önceki yıla göre dramatik düşüş yaşamıştır. Affinity Solutions'ın kredi kartı ve banka kartı datasından yola çıkarak yapılan hesaplamaya göre 2020 Mart ortalarında üst gelir grubunun harcamas1 \%41'lere varan oranda düşerken, bu düşüş en alt gelir grubunda \%12 mertebesinde gerçekleşmiştir (Chetty, Friedman, Hendren, Stepner, The Opportunity Insights Team, 2020, s. 4-20). Ocak 2021'de ikinci devlet desteğinin yatması ardından alt gelir grubunun harcaması \%23'lere varan oranla artmıştır. Harcama yapılan sektörler arasında market alışverişi en büyük artışı yaşarken, eğlence ve rekreasyon en olumsuz etkilenen sektör olmuştur.

1,8 milyon ailenin JP Morgan Chase'deki cari hesaplarının Ocak - Ekim 2020 dönemindeki değişimleri bir önceki yıl ile kıyaslandığında, 2020 Ekim ayında hanehalkı cari hesap dengesinin hükümet destek ödemeleri sayesinde bir önceki yıla göre \%40 daha fazla olduğu, birçok ailenin ise sağlanan ödeneğin hepsini harcamadığı görülmüştür (Farrel, Deadman, Greig ve Noel 2020, s.4). Alt gelir grubu, 2020 Nisan ayında yatırılan devlet desteğinin bir önceki yıla göre hesabındaki meblağda en çok artışa sebep olduğu grup olmuştur ancak bu oran Ekim'e doğru düşmüştür (Farrel vd., 2020, s.4). ABD'de işsizlik desteğinden yararlananların 
destekle birlikte \%22 artan harcamaları, Ağustos 2020'de desteğin sona ermesi harcamalarında \%14 azalmaya sebep olmuş; Mart-Temmuz arası ikiye katladığı birikimlerinin 2/3'ünü Ağustos ayında eritmişlerdir (Farrel ve Ganong, 2020, s.1).

Birleşik Krallık'ta 2020'nin ilk çeyreğinde hanehalkının kullanılabilir gelirine tasarruf oranı \%9,6 olup ikinci çeyreğinde 1987'den itibaren görülmedik orana \%21,9'a yükselmiştir (Francis-Devine, 2021, s.4). 2020'nin ikinci çeyreğinde tasarrufun bu derece artması büyük oranda karantina sebebiyle zaruri olmayan kalemlerin satın alımının azalmasından kaynaklıdır. Üst gelir grubunun harcamasının büyük bir kısmını oluşturan dışarıda yemek, eğlence gibi kalemler yani toplumsal tüketiminin azalması toplam harcamadaki düşüşte önemli rol oynamıştır. Alt gelir grubunun gelirinde zaruri ürünlerin büyük bir orana sahip olması ise harcamalarında aynı oranda düşüşe sebep olmasını engellemiştir (Francis-Devine, 2021, s.6). Resolution Foundation'a göre 2020 yazında çocuk sahibi düşük gelir grubunun \%36'sı harcamasını artırırken, üst gelir grubunun yalnızca \%13'ü artırmıştır (Resolution Foundation, 2021). Bank of England'ın NMG Consulting şirketiyle yaptığı 2020 Ağustos-Eylül arasını kapsayan anket sonuçlarına göre Covid-19 döneminde yüksek gelir grubunun $\% 42$ 'si pandemide daha çok tasarruf yaparken alt gelir grubunun sadece \%22'si daha çok birikim yapabilmiştir (Bank of England, 2020). Haziran 2020 'de Birleşik Krallık'ta yapılan ankete göre bir defalığına mahsus varsayımsal 500 sterlinlik devlet yardımının yapılması halinde ankete katılanların \%81'i önündeki 3 ay boyunca harcamalarını artırmayacağını belirtmiş olup belirsizlik sebebiyle tüketicinin marjinal tüketim eğiliminin ortalama \%11 seviyelerinde kaldığı sonucu çıkmıştır (Crossley, Fisher, Levell, Low, 2021).

Hindistan'da Boston Consulting Group'un Eylül 2020'de 1200 tüketici ile yaptığı anket sonuçlarına göre, ABD ve Birleşik Krallık'taki gibi, pandemi zamanında en çok birikim yapanlar en üst gelir grubundakiler olmuştur (Boston Consulting Group, 2020).

\section{Altından Mücevherin Toplumsal ve Ekonomik İşlevi}

Altından mücevherin anlam ve işlevi, zaman ve mekâna göre farklılık göstermektedir. Genellikle Batı ülkelerinde altından mücevher süs 
amacıyla ve düşük ayar olarak satın alınmakta olup bu tür ürünlerin kar marjı tasarım ve dağıtımı karşılamak üzere daha yüksektir (Corti, 2019, s.6-7). Bu ülkelerde lüks tüketim ürünü olan altından mücevherin, statü göstergesi olarak toplumsal işlevi bulunmaktadır. Fred Hirsch'in tüketicinin fiziksel bir ihtiyacını karşılamasından ziyade toplumsal prestij sağlayan ürünleri belirtmek için kullandığı statü malları ("positional goods") isimlendirmesi altından mücevherin toplumsal yönüne açıklık getirecektir. Birleşik Krallık'ta yatırım aracı olarak mücevherin nasıl satın alınması gerektiğine dair ipuçlarının yayınlanmış olması da mücevherin genellikle mücevherin yatırım aracı olarak görülmediğinin kanıtı olabilecek niteliktedir (Hatton Jewellers, tarih yok).

Asya ve Orta Doğu ülkelerinde ise yüksek ayar ve kar marjı düşük olarak, daha çabuk şekilde altına, nakit paraya dönüştürülebilecek altından mücevher rağbet görmektedir. Bu yönüyle altından mücevher hem lüks tüketim hem lüks tasarruf ürünüdür. Bu sebeple altından mücevherin bu bölgelerde tasarruf ve servet göstergesi olmak üzere ekonomik işlevleri de bulunmaktadır (Neuberger, 2001, s.22) Orta Doğu'da ve Asya'da geleneksel olarak düğünlerde yüksek ayardan altından mücevher hediye olarak takılmaktadır. Orta Doğu'da geleneksel 2122 ayar ürünler rağbet görürken son zamanlarda daha düşük ayarlı, tasarım ve işçiliğin ön plana çıtığı mücevherler de prestij amaçlı satın alınmaya başlamıştır (Moors, 2021, s.81-84).

Çin kültüründe 24 ayar altından mücevher önemli bir yer tutmaktadır. Özellikle kuzey Çin'de düğünlerde yüzük, küpe ve kolyeden oluşan "üç altın" almak bir gelenektir (Daxue Consulting, 2020). Ancak altından mücevheri servet depolama aracı olarak gören tüketicilerin yanı sıra son zamanlarda kimliklerinin ifadesi ve toplumsal tanınma yolu olarak düşük ayar mücevherler de yaygınlaşmaya başlamıştır. Dünya Altın Konseyi'nin tüketici anketi verilerine göre Çin'de bölgeden bölgeye değişen tüketici tercihleri bulunmakta olup Birinci bölgede pırlanta ve platin mücevher ağırlık kazanırken diğer bölgede yüksek ayarlı, servet depolama aracı olarak altın tüketim eğilimi gözlemlenmektedir (Chan, 2018).

Mücevher Hindistan'da gündelik hayatta açık ve görünür şekilde takılmasa da süslenme ve gösterişin norm olduğu dügünlerde kadınların değerini, ailenin prestijini göstermek amaciyla takılan bir statü malı olduğu kadar bir tasarruf aracı olarak da görülmektedir (Gandhi, 2013, 
s.98, 105). Hindistan'da da altından mücevher ailelerin ekonomik olarak zor zamanlardan geçtiği dönemde hılıca ve az kayıpla nakde çevirebildiği için servet saklama işlevi görmektedir (Gandhi, 2013, s.98, 105).

Türkiye' de de altından mücevher hem ekonomik olarak bir servet saklama, yatırım ve tasarruf aracı olarak hem de statü malı olarak değerlendirilmektedir. Diğer mal grupları arasında değerlendirildiğinde mücevher lüks tüketim ürünleri içerisindedir (Ergenç, 2011, s.80). Zaruri ihtiyaçlar arasında görülmeyen, statü göstergesi olarak toplumsal tüketimi olan altından mücevher Türkiye'de minimum değer kaybıyla kolayca nakde çevrilebilmesi özelliği göz önünde bulundurularak daha çok yüksek ayar olarak tüketilmektedir. Geleneklere göre dügünlerde de yüksek ayar mücevher hediye olarak verilmektedir (Ertimur, 2003, s.80).

Lüks ürünler göreceli olup yer, zaman, kültür gibi etmenlere göre değişmektedir (Kasztalska, 2017, s.78). Tarihsel açıdan bakıldığında lüksün kesin bir tanımı olmadığı, herhangi bir ürünün koşullar sağlandığında lüks ürün haline dönüşebildiği görülmektedir (Mortelmans, 2005, s.504). Lüks ürünler çoğu zaman işlevlerinden ziyade sembolik değerleri sebebiyle satın alınırlar. Kısıtlı sayıda üretilip dağıtımı oldukça seçici gerçekleşen lüks ürünleri satın alan kitle kendini seçkin bir gruba ait olduğunu hissetmek ister (Mortelmans, 2005, s.505). Genelde benzersiz bir tasarıma ve kaliteli olan lüks ürünler toplumdaki diğer kişilerin dikkatlerini çekip toplumsal anlamda prestij için satın alınırlar (Mortelmans, 2005, s.507).

Lüks ürünler satın alınmasının ertelenmesi, vazgeçilmesi en kolay ürünler olmuştur (Browning ve Crossley, 2000). Ekonomik daralma dönemlerinde statü mal ve hizmetlerinin verili bir tüketim bütçesindeki harcama payı ise düşme eğilimi göstermektedir (Kamakura ve Du, 2012, s.232). Pandemide geliri düşen aileler için altından mücevher tüketimi ötelenmesi kolay bir ürün olmuştur.

\section{Dünyada ve Türkiye'de Altından Mücevher Tüketimi}

Pandemi döneminde bulaşın azaltılması için alınan önlemler endüstriyel üretimi azalttı. Söz konusu kısıtlamalar altından mücevherin ham maddesi olan altının üretimini de etkiledi. 2020 yılı dünya toplam altın arzının \%72'üne tekabül eden 3.400,8 tonluk kısım madenlerden çıkarılmış olup 
pandemi sebebiyle madenlerdeki üretimin sekteye uğraması sebebiyle 2019 yılına göre \%4 düşmüştür (World Gold Council [WGC], 2021a, s.1617). Bu ise dünya toplam altın arzını 2020 yılında, 2013 yılından sonraki en büyük düşüş oranı olan \%4 ile 4.633,1 tona düşmesine sebep olmuştur.

Pandemi döneminde oluşan belirsizlik, düşük faiz oranları, küresel büyümenin azalması ve risk sebebiyle altın fiyatları yükselmiş olup enflasyon ve düşük faiz oranları insanları güvenli liman olan altına yatırım yapmaya yönlendirmiştir (WGC, 2021b). Bu sebeple gerek fiziki altın olsun gerekse altın ETF'leri olsun 2020 yılında altın yatırımında \%40 artış yaşanmış ve toplam yatırım miktarı 1,773.2 tona yükselmiştir (WGC, 2021a).

Altın fiyatlarının artığı dönemlerde insanların elindeki altını geri dönüştürme eğilimi artmaktadır (WGC, 2018). Ancak 2020'de altın fiyatlarının artmasına rağmen, karantina sebebiyle insanların sokağa çıkmaktan imtina etmesi nedeniyle geri dönüşüm yoluyla altın arzında yer alan kısım ise bir önceki yıla göre sadece \%1 artmıştır (WGC, 2021a, s.18). Geri dönüşümdeki artış oranının küçük olmasında tüketicilerin tasarruf eğilimlerinin artmasınının da etkili olduğu söylenebilir.

Artan belirsizlik, yüksek altın fiyatları, tüketici harcamalarının kısılması 2020'de dünya altın talebinde bir önceki yıla göre \%16'l1k rekor düşüşle toplam 3.675,4 tona gerilemesine sebep olmuştur. Bu da 2020 yılında bir önceki yıla göre \%128 artışla 958 ton altın arz fazlasını yaratmışır (WGC, 2021a, s.1-16).

Tablo 1. 2010-2020 Yılları Arası Dünya Altın Arz ve Talep Miktan ve Değişimi (Ton, \%)

\begin{tabular}{|c|c|c|c|c|c|c|}
\hline \multirow{2}{*}{$\frac{\text { Yil }}{2010}$} & \multicolumn{2}{|c|}{ Altın Arzı (Ton) Değişim (\%) } & \multirow{2}{*}{$\begin{array}{l}\begin{array}{l}\text { Altın Talebi } \\
\text { (Ton) }\end{array} \\
4.177,9\end{array}$} & \multirow{2}{*}{$\begin{array}{l}\text { Değgişim (\%) } \\
14 \%\end{array}$} & \multicolumn{2}{|c|}{ Arz Talep Farkı Değişim (\%) } \\
\hline & 4.315 & & & & 138,1 & \\
\hline 2011 & $4.523,0$ & $5 \%$ & $4.769,7$ & $14 \%$ & $-246,6$ & $-279 \%$ \\
\hline 2012 & $4.542,2$ & $0 \%$ & $4.665,4$ & $-2 \%$ & $-123,2$ & $-50 \%$ \\
\hline 2013 & $4.314,4$ & $-5 \%$ & $4.564,7$ & $-2 \%$ & $-250,3$ & $103 \%$ \\
\hline 2014 & $4.496,2$ & $4 \%$ & $4.411,0$ & $-3 \%$ & 85,1 & $-134 \%$ \\
\hline 2015 & $4.435,3$ & $-1 \%$ & $4.352,6$ & $-1 \%$ & 82,7 & $-3 \%$ \\
\hline 2016 & $4.745,8$ & $7 \%$ & $4.350,8$ & $0 \%$ & 395,0 & $378 \%$ \\
\hline 2017 & $4.594,3$ & $-3 \%$ & $4.284,0$ & $-2 \%$ & 310,3 & $-21 \%$ \\
\hline 2018 & $4.688,8$ & $2 \%$ & $4.436,4$ & $4 \%$ & 252,4 & $-19 \%$ \\
\hline 2019 & 4.819 & $3 \%$ & $4.400,3$ & $-1 \%$ & 419,6 & $66 \%$ \\
\hline 2020 & $4.633,1$ & $-4 \%$ & $3.675,4$ & $-16 \%$ & 957,8 & $128 \%$ \\
\hline
\end{tabular}

Kaynak: (WGC, 2021a, s.1-16). 
2019 yılında toplam altın talebinde mücevherin oranı \%48 iken, 2020 yılında artan altın fiyatları ve değişen tüketici davranışları sebebiyle bu oran rekor düzeye, \%38'e, düşmüştür. Miktar olarak bakıldığında ise 2019 yılında toplam altından mücevher talebinin 2.123 tondan \%34 düşüşle 1.412 tona gerilediği görülmektedir. Altın fiyatlarının yükselmesine rağmen toplam dünya altından mücevher talebinin payı özellikle 2020'nin üçüncü çeyreğinde toparlanmıştır (WGC, 2021a, s.1-16).

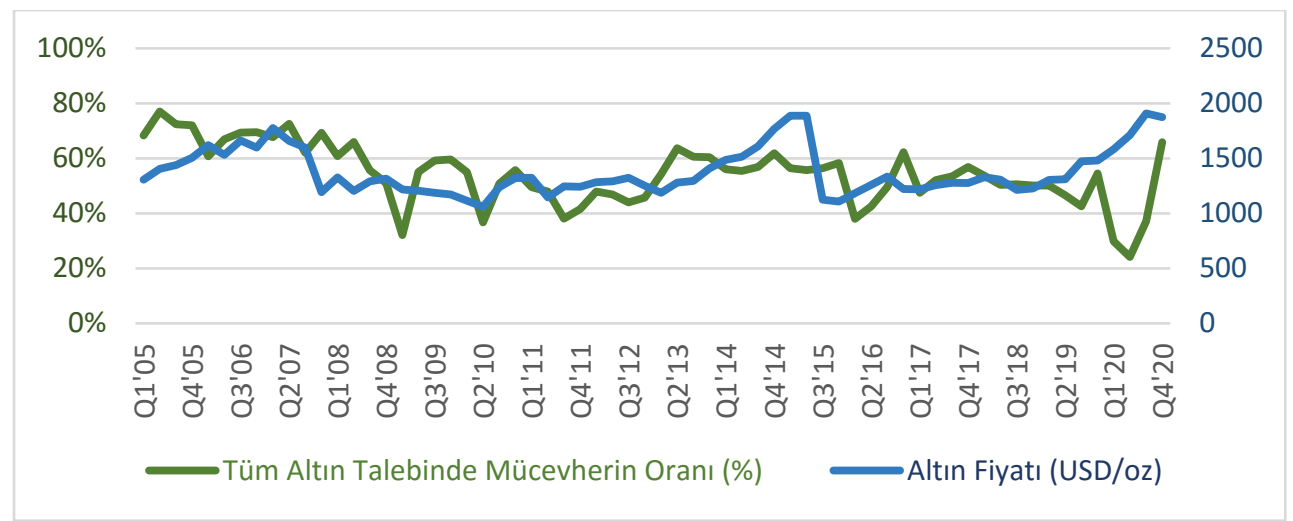

Grafik 1 2005-2020 Arası Çeyrek Bazında Altından Mücevher Talep Miktarının Tüm Altın Talebine Oranı ve Altın Fiyatları (\%, Usd/ons) Kaynak: (WGC, 2021a).

2020 yılındaki \%34'lük altından mücevher talebindeki düşüşte en çok etkili olan ülkeler ise altından mücevheri talebinin yarısından fazlasını gerçekleştiren Çin ve Hindistan olmuştur. 2020'de Hindistan'ın toplam altından mücevher talebi \%42; Çin Anakara'nın \%35 düşüş yaşamıştır. Tüm bu düşüşe rağmen söz konusu iki ülkenin dünya toplam altından mücevher talebindeki payı 2019 yılında \%55'ten 2020 yılında yalnızca \%52'ye gerilemiştir (WGC, 2021a).

2020 yılı altından mücevher talebi çeyrekler bazında detaylı incelendiğinde, pandeminin etkisinin Çin'de ilk çeyrekteki \%67 düşüşle hissedildiği, sonraki çeyreklerde Çin'deki altından mücevher talebinin toparlanmaya başladığı görülmektedir. Mart-Ekim 2020 arası tüketicilerin mücevher alma eğilimlerini araştıran McKinsey ve Company'nin yaptığ1 anket sonuçlarına göre tüketicilerin mücevher alma eğilimlerinin Çin'de 
daha fazladır (McKinsey ve Company, 2020). Çin'deki toparlanma Çin'in altından mücevher hacminin büyük olması sebebiyle 4 . çeyrekte ancak $\% 10$ olarak toparlanabilmiştir. 2021'in ilk çeyreğinde ise biriken talep iç talebi artırmış görünmektedir. Altın Birliği' ne göre 11-17 Şubat arasındaki Bahar Festivali diğer adıyla Çin Yeni Yılı esnasında altın tüketimi bir önceki yıla kıyasla \%80, altından mücevher tüketimi \%161 artmıştır (WGC, 2021).

Tablo 2 . Altından Mücevher Talebi Miktar ve Değişim Oranı (Ton, \%)

\begin{tabular}{|c|c|c|c|c|c|c|c|}
\hline & \multicolumn{6}{|c|}{ 2019-2020 Çeyrekler Bazında Miktar Değişim Oranı (\%) } & \multirow{2}{*}{$\begin{array}{l}\text { 2019-2020 } \\
\text { Yıllık } \\
\text { Değişim } \\
(\%)\end{array}$} \\
\hline & Q1 & Q2 & Q3 & Q4 & 2019 (Ton) & 2020 (Ton) & \\
\hline Dünya Toplam & $-41 \%$ & $-54 \%$ & $-29 \%$ & $-13 \%$ & 2122,7 & 1411,6 & $-34 \%$ \\
\hline Çin Anakara & $-67 \%$ & $-33 \%$ & $-25 \%$ & $-10 \%$ & 638,0 & 415,6 & $-35 \%$ \\
\hline Hindistan & $-41 \%$ & $-74 \%$ & $-40 \%$ & $-8 \%$ & 544,6 & 315,9 & $-42 \%$ \\
\hline $\mathrm{ABD}$ & $-5 \%$ & $-35 \%$ & $-4 \%$ & $-1 \%$ & 131,1 & 118,2 & $-10 \%$ \\
\hline Rusya & $-9 \%$ & $-60 \%$ & $-20 \%$ & $-18 \%$ & 44,5 & 33,3 & $-25 \%$ \\
\hline Türkiye & $-10 \%$ & $-59 \%$ & $-21 \%$ & $-25 \%$ & 36,7 & 26,0 & $-29 \%$ \\
\hline Suudi Arabistan & $-2 \%$ & $-80 \%$ & $-24 \%$ & $-26 \%$ & 37,9 & 25,3 & $-33 \%$ \\
\hline BAE & $-11 \%$ & $-86 \%$ & $-30 \%$ & $-20 \%$ & 34,0 & 21,5 & $-37 \%$ \\
\hline Birleşik Krallık & $-20 \%$ & $-45 \%$ & $-27 \%$ & $-25 \%$ & 21,8 & 15,7 & $-28 \%$ \\
\hline
\end{tabular}

Kaynak: (WGC, 2021a).

Çin'den sonra en büyük altından mücevher tüketicisi olan Hindistan'ın ekonomisini Covid-19 derinden etkilemiştir. Hint kültüründe altından mücevherin toplumsal tüketimine zemin hazırlayan ve tüketimi canlandıran en önemli etkinliği olan düğünlerin karantina sebebiyle gerçekleştirilememesi altından mücevher tüketimine büyük bir darbe vurmuştur. Ayrıca gelirdeki düşüş de zaruri ihtiyaçların önceliklendirilmesine, lüks ürün olan mücevher satışlarının düşmesine sebep olan diğer etmen olmuştur (Goswami ve Chouhan, 2021, s.10262). Hindistan'da GSYİH'nin bir önceki yıla göre \%24,4 daraldığı, Mart ayında kalabalık toplanmaların yasaklanmasıyla dügünlerin yapılamadığ 1 2020'nin ikinci çeyreğinde altından mücevher talebi \%74 ile en keskin düşüşü yaşamış; üçüncü çeyreğinde ise GSYİH'deki daralmanın \%7,5'e gerilmesi altından mücevher tüketimindeki düşüşü ancak \%40'a çekebilmiştir (WGC, 2021a). Eylül ayında önce 100 kişiye, Ekim ayında 200 kişiye kadar toplanmaların izin verilmesi ve dördüncü çeyrekte $\% 0,4^{\prime} l u ̈ k$ 
GSYİH artışı altından mücevher tüketimi düşüşü ivmesini \%8'e kadar geriletmiştir (International Monetary Fund [IMF], 2021).

$\mathrm{ABD}$ altından mücevher tüketiminde ikinci çeyrekte yaşadığı keskin düşüşü üçüncü ve dördüncü çeyrekte düşüş ivmesini azaltarak toparlamış, 2020 toplamında ise bir önceki yıla göre sadece \%10 düşüş yaşanmıştır (WGC, 2021a). ABD'de yüksek gelirli tüketici seyahate harcamadığı parayı mücevhere harcamıştır (Gomelsky, 2020). Pandemide lüks ürün satışları ABD'de beklentilerin üzerinde seyretmiştir (Kavilanz, 2020).

Pandeminin etkisi Türkiye' de 2020'nin ikinci çeyreğinde bir önceki yıla kıyasla \%59'luk keskin düşüşle hissedilmiştir (WGC, 2021a). İkinci çeyrekte altından mücevher talebi rekor miktara, 4,0 tona kadar düşmüştür. Tüketicilerin lüks ürün tüketimini oldukça yüksek oranda azaltması, mücevher sektörünün diğer sektörlere kıyasla daha yavaş toparlanacağ1 öngörüsünü doğurmuştu (Deloitte, 2020). 2020'nin üçüncü çeyreğinde ise gerek biriken talep gerekse de belirsizlik ortamında altından mücevherin yatırım aracı olarak görülmesinin de etkisiyle talepteki düşüş hızı \%21'e gerilemiştir (WGC, 2021a).

Tablo 3 . 2010-2020 Yıllan Arası Dünya Mücevher Talep Miktarı ve Türkiye'nin Mücevher Talep Miktarı (Ton, \%)

\begin{tabular}{llllllllllll}
\hline & $\mathbf{2 0 1 0}$ & $\mathbf{2 0 1 1}$ & $\mathbf{2 0 1 2}$ & $\mathbf{2 0 1 3}$ & $\mathbf{2 0 1 4}$ & $\mathbf{2 0 1 5}$ & $\mathbf{2 0 1 6}$ & $\mathbf{2 0 1 7}$ & $\mathbf{2 0 1 8}$ & $\mathbf{2 0 1 9}$ & $\mathbf{2 0 2 0}$ \\
\hline $\begin{array}{l}\text { Türkiye'nin Talebi } \\
\text { (Ton) }\end{array}$ & 74 & 66 & 80 & 68 & 49 & 41 & 41 & 36 & 37 & 26 \\
$\begin{array}{l}\text { Dünya Toplam Tal- } \\
\text { ebi (Ton) }\end{array}$ & 2.057 & 2.104 & 2.157 & 2.726 & 2.533 & 2.460 & 2.104 & 2.241 & 2.248 & 2.123 & 1.412 \\
$\begin{array}{l}\text { Türkiye'nin Payı } \\
\text { (\%) }\end{array}$ & $3,3 \%$ & $3,5 \%$ & $3,1 \%$ & $2,9 \%$ & $2,7 \%$ & $2,0 \%$ & $1,9 \%$ & $1,8 \%$ & $1,6 \%$ & $1,7 \%$ & $1,8 \%$ \\
\hline
\end{tabular}

2020 yılı genel olarak değerlendirildiğinde ise tüketicilerin 2019 yılında 37 ton olan altından mücevher talebi \%29 oranında azalarak 26 tona gerilemiştir. Dünya toplam altından mücevher talebindeki düşüş Türkiye'deki düşüşten 5 puan daha yüksek olmuştur. Türkiye dünya altından mücevher talebi içerisindeki payını ise 2020 yılında pandemiye rağmen \%1,8'e yükseltmiştir (WGC, 2021a). 


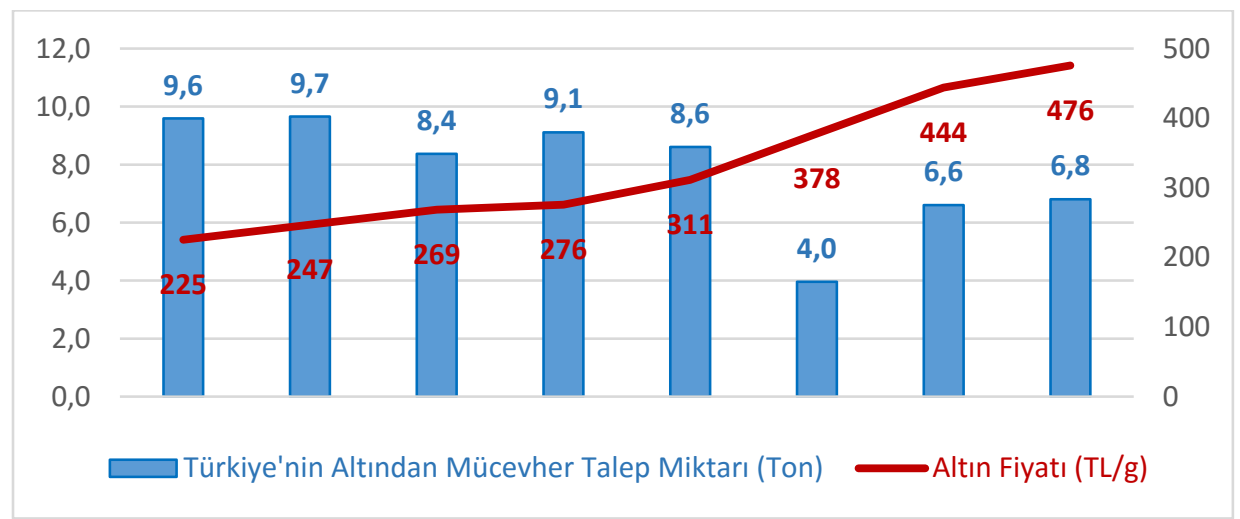

Grafik 2. 2019-2020 Çeyrekler Bazında Türkiye'nin Altından Mamul Mücevherci Eşyası Talep Miktarı ve Altın Fiyatı (Ton, TL/g)

Kaynak: (WGC, 2021a).

Bahsedildiği üzere lüks ürünlerin satın alınmasının bir sebeplerinden birisi de toplumsal açıdan prestij kazanma ve kendini diğerleri arasında farklı gösterme isteğidir. Bunu sağlayan toplumsal bir araya gelişler altından mücevherin toplumsal tüketimini sağlayan mecralardır. Ancak gerek sosyal mesafe kuralları sebebiyle mücevherin toplumsal tüketiminin olmamasına gerekse artan altın fiyatları 2020 yılında Türkiye'nin dünya altın talebindeki payını azaltmaya sebep olamamıştır. 0,1 puanla dahi olsa Türkiye'nin dünya talebindeki payı $\% 1,8$ 'e yükselmiştir. Bunda dünyada altın talebindeki keskin düşüşün yanı sıra altından mücevherin tasarruf ürünü olarak görülmesinin de etkisi bulunmaktadır. Güvenli liman olan altın belirsizlik dönemlerinde başvurulan bir tasarruf aracı olmuştur. $\mathrm{Bu}$ çerçevede söz konusu durum altından mücevherin Türk tüketiciler tarafından lüks tasarruf aracı olarak görüldüğünü de destekler niteliktedir.

Altın fiyatlarının dünya genelinde artması, altından mücevher talebinin düşmesinde etkili olmuştur. Altın fiyatlarının TL bazındaki artış oranının USD bazındaki artış oranına nazaran yüksek olması da Türkiye'deki tüketicilerin bir birim mücevher almak için dünya ortalamasındaki tüketicilerden daha fazla istekli olup daha çok bedel ödemeyi göze aldıkları anlamına gelebilir. 


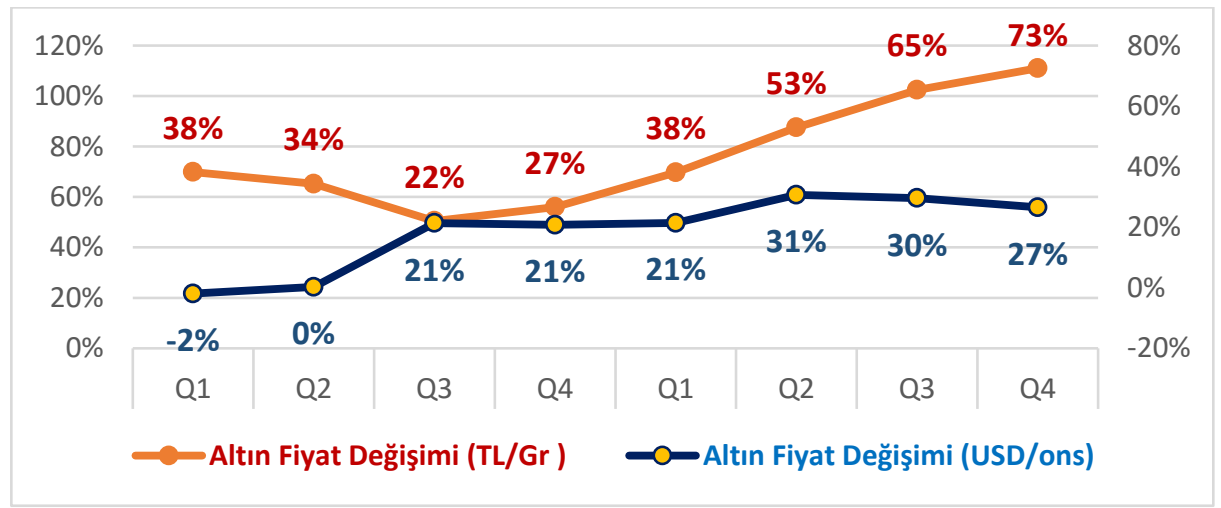

\section{Grafik 3. 2019-2020 Çeyrekler Bazında Altın Fiyatları Değişimi (\%) Kaynak: (WGC, 2021a).}

Pandemi sebebiyle altından mücevherin toplumsal tüketimine mecra açan toplumsal bir araya gelişlerin azalması da dikkate alınırsa, altından mücevherin prestij sağlayan toplumsal tüketimi için daha az zemin oluştuğu varsayılabilinir. Bu duruma dünya genelinde "güvenli liman" olarak altına yatırımın artışı, tüketicilerin tasarruf etme eğilimlerinin kuvvetlenmesi de eklenince pandemi zamanında Türkiye'deki tüketicilerin altından mücevheri daha çok tasarruf işlevini dikkate alarak satın aldığı düşüncesine destek sağlayabilir.

Altından mücevher dış ticaret hacmi dünyada olduğu gibi Türkiye'de de daralmıştır. Uluslararası mücevher satışları iç satışlara göre daha keskin düşüş yaşamıştır (Euromonitor, 2021). Mart 2020'de altından mamul mücevherci eşyası ihracatı \%52 düşmüş olup ocak ve şubat aylarındaki artışlar sebebiyle ilk çeyrekteki düşüş \%12 mertebesinde kalmıştır. Nisan ayında durma noktasına gelen ihracat haziran ayında toparlanmaya başlamıştır. Çeyrek bazında ise en kötü performans \%85'lik düşüşle ikinci çeyrekte gerçekleşmiştir. 
Tablo 4 . 2019-2020 Yılı Çeyrek Dönemli Türkiye'nin Altından Mamul Mücevherci Eşyası İhracat ve İthalat Rakamları ve Değişim Oranı (USD, \%)

\begin{tabular}{lllllll}
\hline & Çeyrek & 2018 (USD) & 2019 (USD) & 2020 (USD) & 2018-2019 Değişim (\%)2019-2020 Değişim (\%) \\
\hline \multirow{4}{*}{ İhracat } & 1. & 910.820 .289 & 1.196 .404 .117 & 1.054 .330 .943 & $31 \%$ & $-12 \%$ \\
& 2. & 1.069 .272 .086 & 1.246 .504 .294 & 184.172 .790 & $17 \%$ & $-85 \%$ \\
& 3. & 1.039 .939 .175 & 973.888 .977 & 838.449 .761 & $-6 \%$ & $-14 \%$ \\
& 4. & 1.171 .027 .892 & 1.422 .648 .831 & 1.295 .646 .102 & $21 \%$ & $-9 \%$ \\
\multirow{4}{*}{ İthalat } & 1. & 172.945 .510 & 421.281 .890 & 208.154 .791 & $144 \%$ & $-51 \%$ \\
& 2. & 147.153 .057 & 278.616 .614 & 147.878 .468 & $89 \%$ & $-47 \%$ \\
& 3. & 177.327 .897 & 434.624 .124 & 161.839 .741 & $145 \%$ & $-63 \%$ \\
& 4. & 249.499 .452 & 360.346 .642 & 152.356 .337 & $44 \%$ & $-58 \%$ \\
\hline
\end{tabular}

Kaynak: (TüIIK, 2021)

Türkiye'nin Altından Mücevher Talebinin 2018-2020 Arası Çeyrek Bazinda Trend Analizi

Dış ticaret verilerinin incelendiği 2018-2020 yılları arasındaki dönemin mücevher talebindeki trend analizi için Mann-Kendall Seasonality Test metodunu kullanmak faydalı olacaktır. Hirsch, Slack ve Smith 1982 tarihinde yayınlanan makalesinde de belirtildiği şekilde, bahsekonu MannKendall Seasonality Test'inin temel amacı, içerisinde mevsimsel etkinin bulunduğu verilerde monoton bir trend olup olmadığını görebilmektir. Parametrik olmayan (Non-Parametric) bir test olduğundan ötürü dağılımdan bağımsız bir şekilde uygulanabilen bu testin tek gerekliliği, verinin içerisinde mevsimselliğin bulunmasıdır. Kullanılan veriler 2018, 2020 yılları arasında çeyrekler olarak toplandığından ötürü, veri çerçevesinde mevsimsellik bulunmaktadır.

Mann-Kendall Seasonality Test trend'i aşağıdaki formül üzerinden görmektedir.

$$
S_{i}=\sum_{k=1}^{n_{i}-1} \sum_{j=k+1}^{n_{i}} \operatorname{sgn}\left(x_{i j}-x_{i k}\right)
$$

Kullanılan formülde, veri çeyrekler bazında bölünmektedir. "i" harfi burada çeyrekleri simgelerken, "n" harfi toplam yıl sayısını belirtmektedir. Her bir "i" sırasındaki çeyrek değeri, diğer yılların aynı " $\mathrm{i}$ " sırasındaki çeyrek değerleri ile karşılaştırılmaktadır. Elde edilen sonuç, $S_{i}$ olarak belirtilen değer, sıfır değerinden büyük olduğunda "+", sıfır değerinden 
küçük olduğunda ise "_-" olarak kodlanmaktadır. Bu $S_{i}$ değeri bütün yıllar ve çeyrekler üzerinden ayrı ayrı hesaplandıktan sonra elde edilen sonuç genel trend konusunda bize bilgi vermektedir.

Testte sıfır hipotezi veride trend olmadığını, alternatif hipotez ise verimizin monotonik bir trend'e sahip olduğunu önermektedir. MannKendall Seasonality Test sonucunda elde edilen p-değeri 0.01877. Bu sonuç \%5 (Tip-1) hata payıyla sıfır hipotezinin reddedilebileceğini söylemektedir. Dolayısıyla veride \%95 olasilıkla monotonik bir trend bulunmaktadır. Söz konusu araştırma kapsamında 2018 ve 2020 yılları arası Türkiye'nin mücevher talebinde grafiklerde gözlemlenen trendi destekleyen sonuca varılmıştır.

\section{Sonuç}

Ekonomik daralmaya sebep olan pandemide dünya genelinde artan işsizlik, hanehalkı gelirindeki değişimler, tüketicinin harcama ve birikim kararına etkisi olan ekonomiye duyduğu güven seviyesi ve gelecek beklentisi, tüketimi etkileyen sebeplerden olmuştur. Altından mamul mücevher eşyası temel ihtiyaçtan ziyade zaruri olmayan, bireysel tüketimin yanı sıra toplum içerisinde görünür bir şekilde tüketilmesinin tüketiciye prestij kattı̆̆ 1 statü malı olarak nitelendirilebilmektedir. Asya ve Orta Doğu'da yüksek ayarlı, hızlıca ve az kayıpla nakde çevrilebilen servet koruma ve tasarruf işlevi olan bir lüks tüketim malı olan altından mücevher talebi altın fiyatlarının yükselmesi, toplumsal tüketim işlevinin ortaya çıkabileceği bir araya gelişlerin azalması ve artan belirsizlik sebepleriyle azalmıştır. Çin ve Hindistan'da hem bir yatırım aracı hem de statü malı olarak görülen altından mücevher talebi 2020'de keskin düşüş yaşamıştır. Çin ekonomisinin pandemiden hızlıca toparlanabilmesi mücevher tüketimine de yansımıştır. Özellikle dünya altından mücevher talebinin yarısından fazlasını gerçekleştiren Çin ve Hindistan'daki düşüş genel ortalamadaki düşüşü oldukça etkilemiştir. ABD'de ise pandemi başlangıcında talep düşmüş olsa da üst gelir grubunun seyahat bütçelerini lüks mücevhere aktarmasıyla beklenmeyen bir artış gerçekleşmiş olup, bu talepteki düşüş oranını küçültmüştür; ülkenin genel ekonomik toparlanmasına bağlı kalmadan 2020'nin üçüncü ve dördüncü çeyreğinde mücevher tüketiminde toparlanma başlamıştır. Türkiye'de de altından 
mücevher tüketimini en çok besleyen evlilik, sünnet gibi kutlamaların sosyal mesafe kuralları çerçevesinde kısıtlanması, altından mücevher tüketimini miktar olarak azaltsa da artan altın fiyatlarına rağmen Türkiye dünya altından mücevher talebindeki payında düşüş yaşamamıştır. Türkiye' de de lüks tasarruf aracı olarak altından mücevher talebi miktar bazında gerilemekle birlikte, artan altın fiyatlarına rağmen dünyadaki payını koruyabilmiştir. Altından mücevherin lüks tasarruf ürünü olarak görülmesi pandemiden hızlıca toparlanmada altından mücevher üreticileri için fırsat sunmaktadır. Bu çerçevede pandemiyle birlikte rağbeti artan çevrimiçi kanalların satış mecrası olarak kullanılması önem teşkil etmektedir. Firmaların çevrimiçi kanalları verimli şekilde kullanması sosyal mesafe kısıtları veya bulaş riski sebebiyle mağazalara gitmeye çekinen müşterilere hitap edebilmeyi sağlayacak, altından mücevher satışlarına olumlu yansiyacaktır. 


\title{
EXTENDED ABSTRACT Gold Jewelry Consumption in Pandemic
}

\author{
Selahattin Armağan Vurdu \\ Istanbul Ticaret University
}

The Covid-19 pandemic has led to the contraction of the global economy, decrease in production and trade volume, increase in uncertainty and change in consumer behavior. Governments have announced support packages in order to eliminate the social and economic damages caused by the pandemic and to increase economic activity and to restore consumer sentiment. However, the increasing uncertainty and the measures taken to prevent the spread of the virus led to an increase in consumer savings, and a decrease in social and luxury expenditures other than essential consumer goods. In this study, the factors affecting consumer purchasing behavior in the pandemic, the demand for gold jewelry as luxury consumption during the pandemic compared with the pre-pandemic gold consumption levels of China, India, the USA and Turkey.

To interpret the consumption figures during that period, the meaning of gold jewelry consumption is explored since the consumer behavior, characteristics of the jewelry consumed and attributed meaning to the jewelry mostly vary by region. In general, in Western countries consumers prefer lower carat jewellery items in order to display their taste and manifest their identities. In addition, buying jewelry which is a luxury rather than an essential need shows the social status. Therefore it also has the social function to reflect prestige. The lower carat jewelry used to manifest identity predominantly has higher profit margin due to the design and distribution costs. In Asia and Middle East people mostly consume high carat gold jewelry which has low profit margin and relatively simple design. One of the reasons of strong demand for high carat pieces in those regions is tradition. High carat gold jewelry given as gift in wedding ceremonies in most of the countries in the region. It was seen as a saving instrument because high carat gold can be easily converted into cash with small losses. Besides, gold jewelry is the signal of higher social status. Some surveys indicate the evolution of perception of the jewelry. Although most of the consumers had a tendency to see gold jewelry as wealth 
storage instrument, young people started to see jewelry as an expression of identity.

During the pandemic the incertainty increased, consumer confidence decreased and gold prices surged. Consumers tend to narrow the expenditure for the status goods and services during an economic contraction. Therefore jewelry consumption was easier to postpone for the households whose incomes have decreased during the pandemic. So reflecting those factors, the gold jewelry demand and share of gold demand from jewelry industry decreased. The gold jewelry demand of the major consumers of the World, China and India, plummeted and affected global gold jewelry demand. India's gold jewelry demand declined by $42 \%$ while China's demand dropped by $35 \%$. As a result world fell by $34 \%$.

On the other side, the high-income consumers, who could not spend on travel and restaurants, tend to purchase jewelry. During the pandemic luxury product sales in the USA were higher than the expected. That is why the gold jewelry demand in the USA fell by \%10 which was well below the world demand drop in 2020. Investors' gold demand has risen due to the fact that gold was perceived as "safe haven". Pandemic related social distance measures prevented social gatherings which were crucial to show display the jewelry owned.

In Turkey, gold jewelry demand was hit hard especially in the second quarter of 2020. Even though there were inhibiting factors such as social gathering constraints and gold price hikes, the share of gold jewelry demand of Turkey rose from 1,7\% to 1,8\% in 2020. Furhermore the decrease in gold jewelry demand of Turkey is below the world demand loss percentage. The world gold jewelry demand decreased by $34 \%$ in 2020 , while Turkey's gold jewelry demand was down $29 \%$. It manifests the dual role of gold jewelry both as a luxury and a saving method.

International trade volume of gold jewelry has shrunk as the Covid-19 pandemic disrupted global trade. Although in March Turkey's jewelry export fell by $52 \%$, the drop in export remained around $12 \%$ in the first quarter thanks to the export volume in January and February. Turkish jewelry exports, which came to a standstill in April, started to recover in June. The sharpest drop in jewelry export occurred in the second quarter with a decline of $85 \%$. 
In this study, the Mann-Kendall Seasonality Test is used for jewelry demand trend analysis. In the test, the null hypothesis suggests that there is no trend in the data, while the alternative hypothesis suggests that our data has a monotonic trend. The p-value obtained as a result of the MannKendall Seasonality Test is 0.01877 . This result says that the null hypothesis can be rejected with a 5\% (Type-1) margin of error. Therefore, there is a $95 \%$ probability that there is a monotonic trend in the data. Within the scope of the research in question, it was concluded that Turkey's jewelry demand between 2018 and 2020 supports the trend observed in the graphics.

\section{Kaynakça / References}

Baker, S. R., Bloom, N., Davis, S. J. ve Terry, S. J. (2020, Nisan). Covid induced economic uncertainty. (NBER Working Paper No. 26983). doi:10.3386/w26983.

Baker, S. R., Farrokhnia, R. A., Meyer, S., Pagel, M. ve Yannelis, C. (2020, Nisan). How does household spending respond to an epidemic? Consumption during the 2020 Covid-19 pandemic. . (NBER Working Paper No. 26949). doi:10.3386/w26949.

Bank Of England. (2020, Kasım 25). How has Covid affected household savings? 25 Mart 2021 tarihinde, https://www.bankofengland.co.uk/bankoverground/2020/how-has-covid-affected-household-savings adresinden erişildi.

Bertrand, M., Dizon-Ross, R., Krishnan, K. ve Schofield H. (2020). Employment, Income, Consumption in India During and After Lockdown: A V-Shape Recovery? 22 Mart 2021 tarihinde, https://www.chicagobooth.edu/research/rustandy/blog/2020/employment-income-and-consumption-in-india-during-and-after-the-lockdown. $\%$ C2\%A0 adresinden erişildi.

Boston Consulting Group. (2020). How India Spends, Shops and Saves in the New Reality? 5 Nisan 2021 tarihinde, https://web-assets.bcg.com/7c/d0/4658d6074223b9cbc5ec677d6035/bcg-how-indiaspends-shops-saves-in-the-new-reality-for-distribution.pdf adresinden erişildi. 
Browning, M. ve Crossley, T. F. (2000, Ekim). Luxuries are easier to postpone: A proof. Journal of Political Economy, 108(5), 1022-1026. https://doi.org/10.1086/317668.

Bureau of Labour Statistics. (2021). The Employment Situation- March 2021. 7 Nisan 2021 tarihinde, https://www.bls.gov/news.release/pdflempsit.pdf adresinden erişildi.

Chan, G. (2018). Potential for growth in China's jewellery market. 21 Mart 2021 tarihinde, https://www.gold.org/goldhub/research/gold-investor/goldinvestor-october-2018/potential-for-growth-in-chinas-jewellery-market adresinden erişildi.

Chetty, R. J., Friedman, J. N., Hendren, N., Stepner, M., The Opportunity Insights Team. (2020, Kasım). How did Covid-19 and stabilization policies affect spending and employment? A new real-time economic tracker based on private sector data. (NBER Working Paper No. 27431). doi: $10.3386 / \mathrm{w} 27431$.

Centre for Monitoring Indian Economy [CMIE]. (2021). Unemployment Rate in India. Mart 10, 2021 tarihinde, https://unemploymentinindia.cmie.com/ adresinden erişildi.

Corti, C. W. (2019) Jewellery Alloys- Past, Present and Future. The Goldsmiths' Company Jewellery Materials Congress, Londra. 29 Mart 2021 tarihinde, https://www.assayofficelondon.co.uk/media/2560/jewellery-alloys-past-present-future-c-corti.pdf adresinden erişildi.

Crossley, T. M., Fisher, P., Levell, P. Low, H. (2021). MPCs through Covid: Spending, saving and private transfers. (IFS Working Paper No. 21/03) doi:10.1920/wp.ifs.2021.321

Daxue Consulting. (2020). How millenials and low-tier cities are shaping China's jewelry market. 2 Nisan 2021 tarihinde, https://daxueconsulting.com/how-millenials-and-low-tier-cities-are-shaping-chinas-jewelrymarket/ adresinden erişildi.

Deloitte. (2020, Nisan). Küresel Covid-19 Salgınının Türkiye'de Farklı Kategorilere Etkileri. 5 Mart 2021 tarihinde, https://www2.deloitte.com/tr/tr/pages/consulting/articles/kuresel-covid-19salgininin-turkiyede-farkli-kategorilere-etkileri.html adresinden erişildi.

Ergenç, Ü. (2011). Engel eğrileri: Türkiye örneği incelemesi. (Yüksek lisans tezi). Ankara Üniversitesi, Sosyal Bilimler Enstitüsü, İktisat Ana Bilim Dalı, Ankara. Ankara Üniversitesi Akademik Arşiv Sistemi (http://hdl.handle.net/20.500.12575/30142). 
Ertimur, B. (2003). Gold and gold jewelry: Exploration of consumer practices. (Yüksek lisans tezi). İhsan Doğramacı Bilkent Üniversitesi, Sosyal Bilimler Enstitü, İşletme Ana Bilim Dalı, Ankara. Bilkent University Institutional Repository (http://hdl.handle.net/11693/29350).

Euromonitor. (2021). Luxury Jewellery in Turkey. 29 Mart 2021 tarihinde, https://www.euromonitor.com/luxury-jewellery-in-turkey/report adresinden erişildi.

Eurostat. (2021). Unemployment by sex and age - monthly data. 28 Mart 2021 tarihinde, https://ec.europa.eu/eurostat/databrowser/view/UNE_RT_M_custom_730921/default/table?lang=en adresinden erişildi.

Farrell, D., Ganong, P., Greig, F., Liebeskind, M., Noel, P., Sullivan, D. ve Vavra, J. (2020). The unemployment benefit boost: Initial trends in spending and saving when the $\$ 600$ supplement ended. 13 Mart 2021 tarihinde, https://www.jpmorganchase.com/institute/research/labor-markets/the-unemployment-benefit-boost adresinden erişildi.

Farrell, D., Deadman, E., Greig, F. ve Noel, P. (2020). Household cash balances duing Covid-19: A distributional perspective. 13 Mart 2021 tarihinde, https://www.jpmorganchase.com/institute/research/household-incomespending/household-cash-balances-during-covid-19-a-distributional-perspective\#infographic-text-version-uniqId1615496316634 adresinden erişildi.

Francis-Devine, B. (2021). Coronavirus: Impact on household saving and debt. (House of Commons Library Briefing Paper No. CBP9060) 19 Mart 2021 tarihinde, https://commonslibrary.parliament.uk/research-briefings/cbp-9060/ adresinden erişildi.

Federal Reserve Bank of St. Louis. (2021). Deposits, all commercial banks. 29 Mart $2021 \quad$ tarihinde, https://fred.stlouisfed.org/series/DPSACBW027SBOG adresinden erişildi.

Gandhi, A. (2013). A Superlative Form: How Gold Mediates Personhood and Property in Mumbai. Etnofoor, 25(1), 91-110. 28 Mart 2021 tarihinde, https://www.jstor.org/stable/43264011 adresinden erişildi.

Gomelsky, V. (2020). Even in a pandemic, fine jewelry is selling. 15 Mart 2021 tarihinde, https://www.nytimes.com/2020/12/03/fashion/jewelry-risingsales-pandemic-.html adresinden erişildi.

Goswami, S. ve Chouhan, V. (2021). Impact of change in consumer behaviours and need prioritisation on retail industry in Rajasthan during Covid- 
19 Pandemic. Materials Today: Proceedings, 46 (20), 10262-10267. https://doi.org/10.1016/j.matpr.2020.12.073.

Hatton Jewellers. (tarih yok). A Guide to Buying Jewellery As An Investment. 12 Mart 2021 tarihinde, https://www.hatton-jewellers.com/blog/investment-jewellery-guide-to-buying adresinden erişildi.

Hirsch, F. (1976). The social limits to growth. Cambridge, MA: Harvard University Press.

Hirsch, R.M., Slack J. R. ve Smith, R. A. (1982). Techniques of trend analysis for monthly water quality data. Water Resources Research, 18(1), 107121. https://doi.org/10.1029/WR018i001p00107

International Monetary Fund [IMF]. (2021). World Economic Outlook Update. 12 Mart 2021 tarihinde, https://www.imf.org/en/Publications/WEO/Issues/2021/01/26/2021-world-economic-outlook-update\#: :text=Amid\%20exceptional\%20uncertainty $\% 2$ C $\% 20$ the $\% 20$ global, and $\% 204.2 \% 20$ percent $\% 20$ in $\% 202022$.Etext=Many $\% 20$ countries $\% 2$ C $\% 20$ particularly $\% 20$ low $\% 2$ Dincome,rise $\% 20$ further $\%$ adresinden erişildi.

International Monetary Fund. Policy Responses to Covid-19. 12 Mart 2021 tarihinde, https://www.imf.org/en/Topics/imf-and-covid19/Policy-Responses-to-COVID-19\#U adresinden erişildi.

Kasztalska, A. (2017). The economic theory of luxury goods. International Marketing and Management of Innovations: International Scientific E-Journal, 2, 77-87. 17 Ağustos 2021 tarihinde, http://immi.ath.bielsko.pl/wp-content/uploads/2017/06/7 1.pdf adresinden erişildi.

Kavilanz, P. (2020). The rich really are different: They're buying more jewelry during Covid. 19 Mart 2021 tarihinde, https://edition.cnn.com/2020/10/19/business/fine-jewelry-pandemic/index.html adresinden erişildi.

Kose, M. A., Ohnsorge, F. ve Vorisek, D. (2021). Impact of Covid-19 on emerging market \& developing economies. Japan Spotlight, 40, 13-17.

Kamakura, W.A. ve Du R. Y. (2012, Ağustos). How economic contractions and expansions affect expenditure patterns. Journal of Consumer Research, 39(2), 229-247. https://doi.org/10.1086/662611.

McKinsey ve Company. (2020, Ekim 26). Consumer Sentiment and Behavior Continue to Reflect the Uncertainty of the COVID-19 Crisis. 22 Mart 2021 tarihinde, https://www.mckinsey.com/business-functions/marketing- 
and-sales/our-insights/a-global-view-of-how-consumer-behavior-is-changing-amid-covid-19 adresinden erişildi.

Moors, A. (2013). Wearing gold, owning gold: The multiple meanings of gold jewellery. Etnofoor, 25(1), 78-89.

Mortelmans, D. (2005). Sign values of distinction. The concept of luxury. Semiotica, 157(1/4), 497-520. doi:10.1515/semi.2005.2005.157.1-4.497

Neuberger, A. (2001). Gold Derivatives: The market impact. 22 Mart 2021 tarihinde, https://www.gold.org/goldhub/research/gold-derivatives-marketimpact adresinden erişildi.

Organisation for Economic Co-operation and Development [OECD]. (2020, Kasim 12). Growth and economic well-being: Government support measures continue to shield household income from economic impact of COVID-19 in second quarter of 2020. 22 Mart 2021 tarihinde, http://www.oecd.org/sdd/na/Growth-and-economic-well-being-oecd-112020.pdf adresinden erişildi.

OECD. (2021a, Şubat 4). Growth and economic well-being: OECD household income grows slightly in the third quarter of 2020 despite GDP rebound. 22 Mart 2021 tarihinde, https://www.oecd.org/sdd/na/Growthand-economic-well-being-oecd-01-2021.pdf adresinden erişildi.

OECD. (2021b, Mart 9). OECD Economic Outlook, interim report march 2021. doi:https://doi.org/10.1787/34bfd999-en

Refinitiv. (2021, Mart 23). COVID-19 stimulus payments boost savings rather than spending. 2 Nisan 2021 tarihinde, https://static1.squarespace.com/static/5a17333eb0786935ac112523/t/605c9 2807cca1206e17cea7e/1616679554250/Refinitiv+Surplus+Check+Report.pdf adresinden erişildi.

Resolution Foundation. (2021, Ocak 11). Why families on a low income are spending more during Covid-19. 18 Mart 2021 tarihinde, https://www.resolutionfoundation.org/publications/pandemic-pressures/ adresinden erişildi.

Romei, V. ve Giles, C. (2021, Şubat 12). UK Suffers Biggest Drop in Economic Output in 300 Years. Financial Times. 15 Mart 2021 tarihinde, https://www.ft.com/content/96e19afd-88b3-4e8d-bc3e-a72bd1f60d3c adresinden erişildi.

Roy, S., Dutta, R. ve Ghosh, P. (2021). Recreational and Philanthropic Sectors are the Worst-Hit US Industries in the COVID-19 Aftermath. Social 
Sciences and Humanities Open, 3(1), 1-5. https://doi.org/10.1016/j.ssaho.2020.100098.

STATISTA. (2021, Mart 19). Impact on household income due to the coronavirus (COVID-19) in India from February to April 2020. 29 Mart 2021 tarihinde, https://www.statista.com/statistics/1111510/india-coronavirusimpact-on-household-income/\#: :text=Household\%20income\%20in\%20India\%20was,45.7\%20percent\%20in\%20mid\%20April. adresinden erişildi.

The world's consumers are sitting on a pile of cash. Will they spend it? (2021, Mart 9). The Economist. 10 Mart 2021 tarihinde, https://www.economist.com/finance-and-economics/2021/03/09/the-worlds-consumers-are-sitting-on-a-pile-of-cash-will-they-spend-it adresinden erişildi.

Türkiye İstatistik Kurumu [TÜİK]. (2021) Iş̧ücü İstatistikleri, Ocak 2021. 12 Mart 2021 tarihinde, https://data.tuik.gov.tr/Bulten/Index? $p=I$ sgucuIstatistikleri-Ocak-2021-adresinden erişildi.

World Gold Council (2018, Nisan). Gold market primer: Gold recycling. 20 Mart 2021 tarihinde, https://www.gold.org/goldhub/research/market-primer/recycling adresinden erişildi.

World Gold Council. (2021a). Gold demand trends full year and Q4 2020. 6 Mart 2021 tarihinde, https://www.gold.org/goldhub/research/gold-demandtrends adresinden erişildi.

World Gold Council. (2021b, Ocak). Gold Outlook 2021 economic recovery and low interest rates set the tone. 6 Mart 2021 tarihinde, https://www.gold.org/goldhub/research/outlook-2021 adresinden erişildi.

World Gold Council. (2021c, Mart 5). Chinese gold consumption booms during the 2021 Chinese new year holiday. 16 Mart 2021 tarihinde, https://www.gold.org/goldhub/gold-focus/2021/03/chinese-gold-consumption-booms-during-2021-chinese-new-year-holiday adresinden erişildi.

\section{Kaynakça Bilgisi / Citation Information}

Vurdu, S. A. (2021). Pandemide altından mücevher tüketimi. OPUS-Uluslararası Toplum Araştırmaları Dergisi, 18(43), 7220-7246. DOI: 10.26466/opus. 941168. 